George R. Boyer

\title{
The Evolution of Unemployment Relief in Great
}

Britain Unemployment was a major cause of economic insecurity for British workers throughout the nineteenth century. Business-cycle downturns occurred every five to eight years, and more than one-quarter of the years from 1834 to 1911 were plagued by high levels of cyclical unemployment. Even during prosperous years, many workers in seasonal or casual occupations experienced prolonged periods of unemployment. The average worker's savings were modest. A spell of unemployment longer than a few weeks led most manual workers to experience "acute financial" distress, forcing them to turn to other sourcestypically local government or charities-for income assistance. ${ }^{1}$

Relatively little has been written about unemployment relief during the period between the passage of the Poor Law Amendment Act in $1834{ }^{\text {an }} \mathrm{d}$ the adoption of national unemployment insurance in 1911. This study is an attempt to help fill the gap in the literature. It examines the changing roles played by poor relief, private charity, trade unions, and public employment in the lives of the urban unemployed during cyclical downturns from 1834 to 1911. The story that emerges offers no support for a "Whig theory of welfare." Public assistance for the unemployed was more generous, and more certain, from 1834 to 1870 than it was from 1870

George R. Boyer is Professor of Labor Economics, Cornell University. He is the author of An Economic History of the English Poor Law, 17301830 (Cambridge, 1990); co-author, with Timothy J. Hatton, of "New Estimates of British Unemployment, 1870-1913, "Journal of Economic History, LXII (2002), 643-675.

The author would like to thank Stanley Engerman, Christopher Hanes, Timothy Hatton, Frank Lewis, David Mitch, James Riley, and an anonymous referee for helpful comments.

(C) 2003 by the Massachusetts Institute of Technology and The Journal of Interdisciplinary History, Inc.

1 Business-cycle downturns occurred in 1837/38, 1841-1843, 1848/49, 1857/58, 1862, 1867/68, 1878/79, 1885-1887, 1893-1895, 1904/05, and 1908/09. See Boyer and Timothy J. Hatton, "New Estimates of British Unemployment, 1870-1913, "Journal of Economic History, LXII (2002), 643-675; Charles H. Feinstein, National Income, Expenditure and Output of the United Kingdom, 1833-1963 (Cambridge, 1972), T125-126; Walt W. Rostow, British Economy of the Nineteenth Century (Oxford, 1948), 123-125. The best discussion of the extent of workers' savings during the nineteenth century is Paul Johnson, Saving and Spending: The Workingclass Economy in Britain 1870—1939 (Oxford, 1985), 87-125. 
to 1911 , and the adoption of national unemployment insurance in 1911 was more of a repudiation of late nineteenth-century public relief policies than an extension of them. ${ }^{2}$

Most industrial cities continued to grant outdoor relief to cyclically unemployed males from 1834 through the late 1860s. However, local poor rates were not capable of indefinite expansion, and during serious downturns, charitable organizations mobilized to raise money to help meet the high demand for assistance.

A major change in public policy toward the unemployed occurred in the 1870s when cities throughout Britain sharply curtailed the payment of outdoor relief to able-bodied males. During downturns, local governments and charities adopted ad hoc methods for relieving the unemployed, and many skilled workers received unemployment benefits from their trade unions. The policy shift of the 1870s was a response to the Poor Law crises in London and Lancashire in the 1860s. The new solution proved no better at relieving the nonunionized unemployed-or preventing unemployment - than the Poor Law had been. The problems associated with relying on ad hoc emergency relief funds became apparent during the downturn of $1885 / 86$, and the government

2 The one major work on this period is Jose Harris, Unemployment and Politics: A Study in English Social Policy 1886-1914 (Oxford, 1972), but it covers only the three decades leading up to World War I. It deals more with the political aspects of unemployment relief than with the actual workings of local relief policies. William H. Beveridge, Unemployment: A Problem of Industry (London, 1909), 150-191; Sidney Webb and Beatrice Webb, The Minority Report of the Poor Law Commission. Part II. The Public Organization of the Labour Market (London, 1909), 99-162, provide useful summaries of unemployment policies before 1914. Several studies of unemployment relief in a particular city at a particular time have been published. These include Frank Tillyard, "Three Birmingham Relief Funds 1885, 1886, and 1905," Economic Journal, XV (1905), 505-520; Edward G. Howarth and Mona Wilson, West Ham: A Study in Social and Industrial Problems (London, 1907), 337-384; Gareth Stedman Jones, Outcast London: A Study in the Relationship between Classes in Victorian Society (Oxford, 1971); James H. Treble, "Unemployment and Unemployment Policies in Glasgow 1890-1905," in Pat Thane (ed.), The Origins of British Social Policy (London, 1978), 147-172; T. Christopher Smout, "The Strange Intervention of Edward Twistleton: Paisley in Depression, 1841-3," in idem (ed.), The Search for Wealth and Stability (London, 1979), 218-242; Alan Kidd, "Charity Organization and the Unemployed in Manchester c. 1870-1914," Social History, IX (1984), 45-66; Keith Gregson, "Poor Law and Organized Charity: The Relief of Exceptional Distress in North-East England, 1870-1910," in Michael E. Rose (ed.), The Poor and the City: The English Poor Law in Its Urban Context, 1834-1914 (New York, 1985), 94-131. Quotation from Rose, "The Crisis of Poor Relief in England, 1860-1890," in Wolfgang J. Mommsen (ed.), The Emergence of the Welfare State in Britain and Germany, 18301930 (London, 1981), 52, who also rejects the "Whig theory of welfare." 
responded by encouraging municipalities to set up work relief projects to aid the unemployed. However, the downturns of 1893 to 1896 and $1904 / 05$ revealed the inability of municipal work-relief programs to assist temporarily unemployed workers. From 1886 onward, each business-cycle downturn put additional pressure on Parliament to set up a national system of unemployment relief

The adoption of compulsory unemployment insurance in 1911, paid for, in part, by a government subsidy, represented another about-face in policy. Parliament's decision to set up a national system of unemployment insurance owed much to the lessons learned from the workings of trade-union unemployment schemes and the various forms of local unemployment relief from 1870 to 1911.

UNEMPLOYMENT RELEF, 1834-1870 The Poor Law remained an important source of income assistance to cyclically unemployed workers for at least three decades after the passage of the Poor Law Amendment Act in 1834. The Poor Law Commission and its replacement, the Poor Law Board, issued acts to restrict the payment of relief outside of workhouses to able-bodied males in 1842, 1844, and 1852, but these orders were evaded by urban Poor Law unions throughout England and Wales, especially during cyclical downturns. Workers viewed the right to outdoor relief-relief at home rather than in a workhouse-when unemployed as part of an "unwritten social contract" with employers, and most local relief administrators in industrial cities agreed.

The Poor Law was administered at the local level. Before 1865, each parish within a Poor Law union was responsible for relieving its own poor. Poor relief was financed by a property tax,

3 Poor Law unions were local government units, consisting of several parishes, established by the Poor Law Commission after 1834 to administer poor relief. Prior to 1834, the parishes alone were responsible for upholding the Poor Law. See Rose, "The New Poor Law in an Industrial Area," in R. M. Hartwell (ed.), The Industrial Revolution (Oxford, 1970), 121-143. Lynn Hollen Lees, The Solidarities of Strangers: The English Poor Laws and the People, 17001948 (Cambridge, 1998), 179-196, found that three London parishes and six provincial towns c. 1850 had large numbers of prime-age males who continued to apply for relief, a majority of whom were granted outdoor relief. In Manchester during the downturn of 1847/48, "outdoor relief rose and fell with a lag of about six weeks with each rise and fall in factory employment" (H. Mac Boot, "Unemployment and Poor Law Relief in Manchester, 1845-50," Social History, XV [1990], 217-228). See also Boyer, "Poor Relief, Informal Assistance, and Short Time during the Lancashire Cotton Famine," Explorations in Economic History, XXXIV (1997), $56-76$. 
known as the poor rate, assessed on "land, houses, and buildings of every description" within the parish, but not on firms' profits or stock in trade. Machinery generally was not taken into account in estimating the rateable value of factory buildings. As a result of this system of assessment, a large share of the poor rate was levied on the occupiers of dwelling houses. Table $\mathrm{i}$ shows the distribution of poor-rate assessments in six Lancashire cities in 1848/49. In each city, the majority of collected assessments were valued at less than $£ 8$, and 82 percent or more of the assessments were valued at less than $£ 10$. An 1842 report by the assistant Poor Law commissioners concerning Stockport classified all assessments of $£ 8$ or less as working-class dwellings, and classified assessments of $£ 8$ to ${ }^{\wedge} 20$ as dwellings of foremen, clerks, small shopkeepers, and "persons of small independent means." Assessments of more than $£ 20$ included the "higher classes of private residences," large shopkeepers, and publicans, as well as factories. Table 1 also presents the estimated contribution of assessments valued at less than $£ 8$ and $£ 20$ in the three cities for which the total value of rateable property is known. The results suggest that assessments on workingclass dwellings contributed 14 to 29 percent of the poor rate, and that all assessments valued at less than $\wedge 20$ contributed up to 45 percent of the poor rate. ${ }^{4}$

The assessment system had important implications regarding who paid for unemployment relief. Ratepayers can be divided into three groups-factory owners and other major employers of labor, workers, and the remaining ratepayers (merchants, shopkeepers, landlords, tradesmen, etc.). The share of the poor rate paid by factory owners in Lancashire cities is not possible to determine precisely. If manufacturers paid between one-half and twothirds of the rate collected from assessments of $£ 20$ or more, they contributed 27 to 46 percent of the poor rate in these cities, "a distinctly modest contribution to local expenditure." Because the poor rate was levied on the occupiers of dwelling houses rather than the owners, workers, most of whom rented their tenements,

4 See Rose, "The Administration of Poor Relief in the West Riding of Yorkshire c. 18201855," unpub. D. Phil, thesis (Univ. of Oxford, 1965), 348-359. "Collected" assessments refer to paid assessments, as opposed to defaulted ones. Default rates were higher on assessments valued at less than $j T \%$ than on those valued at $£ 20$ or more. The Assistant Commissioners' report can be found in Parliamentary Papers, Report of the Assistant Poor Law Commissioners ... on the State of the Population of Stockport (1842, XXXV), 198. 
Table $l$ Poor Rate Assessments in Lancashire Cities, 1848/49

\begin{tabular}{|c|c|c|c|c|c|c|}
\hline \multirow[b]{2}{*}{ CITY } & \multirow{2}{*}{$\begin{array}{l}\text { TOTAL NUMBER } \\
\text { OF ASSESSMENTS }\end{array}$} & \multicolumn{2}{|r|}{$\begin{array}{r}\% \text { OF COLLECTED } \\
\text { VALUED }\end{array}$} & $\begin{array}{l}\text { ASSESSMENTS } \\
\text { AT: }\end{array}$ & \multicolumn{2}{|c|}{$\begin{array}{c}\text { ESTIMATED \% OF POOR RATE } \\
\text { COLLECTED FROM ASSESSMENTS } \\
\text { VALUED UNDER }\end{array}$} \\
\hline & & LESS & THAN $\mathfrak{f 8}$ & $£ 20$ OR MORE & $£ 8$ & $£ 20$ \\
\hline Ashton-under--Lyne & 11,265 & & $84.8 \%$ & $5.7 \%$ & $28.9 \%$ & $41.5 \%$ \\
\hline Blackburn & 7,272 & & $71.6 \%$ & $10.2 \%$ & & \\
\hline Bolton & 5,966 & & $68.0 \%$ & $11.7 \%$ & & \\
\hline Manchester & 37,750 & & $51-5 \%$ & $18.0 \%$ & $13-9 \%$ & $31.8 \%$ \\
\hline Oldham & 10,414 & & $80.6 \%$ & $1.5 \%$ & & \\
\hline Preston & $\mathrm{n}, 397$ & & $734 \%$ & $10.0 \%$ & $27.2 \%$ & $45.1 \%$ \\
\hline
\end{tabular}

SOURCES Data on poor-rate assessments from Parliamentary Papers, Returns Relating to Rating of Tenements in Lancashire, Suffolk, Hampshire, and Gloucestershire (1849, XLVII), 10-15. Data on total value of rateable property are from Parliamentary Papers, Returns Relative to Poor Rates, County Rates, Population, \&c. (1847/

48, LIH), 176. 
paid part of the tax, though some of the tax levied on occupiers would have been shifted to their landlords. Non-labor-hiring middle-class taxpayers paid one-quarter or more of the poor rate. The more successful working-class occupiers were in shifting the rates on dwelling houses to their landlords, the larger was the share of the poor rate paid by middle-class taxpayers. ${ }^{5}$

During most downturns, the Poor Law was capable of dealing with the increased demand for relief caused by unemployment. However, in many cities during the depression of 1841/42 and the Lancashire cotton famine of 1861 to 1865 , the Poor Law was unable to meet the demand for assistance, not only because the number of unemployed workers increased but also because the effective tax base declined as a result of a sharp increase in the default rate of taxpayers. The use of a simple model reveals the problem faced by parishes during downturns. A parish's supply of poor-relief funds at a point in time $t$ can be written as $r_{t}(l-d)_{t} V$, where $r$ is the poor (tax) rate, $d$ is the default rate, and Fis the total value of rateable property in the parish. Relief expenditures at time $t$ are equal to $g_{t}^{A} P_{y}$ where $g$ is the generosity of relief, $\mathbf{5}$ is the share of the local population being granted relief, and Pis the population of the parish. Setting tax revenue equal to relief expenditures yields the equation $r_{t}(i \sim d)_{t} V=g f_{t} P$. Rearranging terms, the poor rate at time $t i s$ determined as $r_{t}=g^{A}{ }_{t} P /(i-d)_{t} V$. In recession years, the share of the population granted relief increased, the parish's value of rateable property often declined, and the default rate increased. In order to assist everyone who applied for relief, parishes were forced to increase the poor rate or reduce the generosity of relief. However, increases in the poor rate tended to

5 David Eastwood, Government and Community in the English Provinces, 1700-1870 (New York, 1997), 79. A detailed poor-rate assessment for Sheffield, West Yorkshire, in 1834 indicates that dwelling houses paid $74.1 \%$ of the poor rate, and factories paid only $16.6 \%$. See Rose, "Administration of Poor Relief," 349. Factories' contributions to the poor rate surely were greater in the cotton-textile district of south Lancashire in the 1840s. In 1869, Parliament adopted the Poor Rate Assessment and Collection Act, which empowered parish vestries to assess the owners of dwelling houses "which do not exceed a certain prescribed limit of rateable value," rather than the occupiers. See G. H. Blunden, Local Taxation and Finance (London, 1895), 27-28. The fact that Parliament felt it necessary to pass such an act suggests that before 1869, working-class occupiers of dwelling houses paid at least a share of the poor rate. There is very little information about landlords in industrial cities. Some employers built and owned cottages in which their workers lived, but mostly in smaller industrial towns, where housing was particularly scarce. In larger cities, employers probably owned only a small share of working-class housing, the majority of it owned by non-labor-hiring, middle-class taxpayers. 
cause further increases in the default rate. There was a maximum beyond which parishes refused to raise the poor rate.

Table 2 gives the particulars of each of Stockport's poor-rate assessments from October 1836 to June 1841. During downturns, as in 1838 and 1841, two or more assessments often took place per year. There were three assessments in 1841-in February, June, and November-totaling four shillings (45.) in the pound. The 25. assessment in November was necessary because the number of relief recipients increased by 63 percent from June to December 1841. Default rates increased sharply during the 1841 recession. In October 1836, a time of prosperity, 92 percent of the assessed poor rate was actually collected. However, as a result of the large number of defaulters, only 63 percent of the rates levied in February and June 1841 were collected. When Stockport collected its poor rate in November 1841, 1,632 of 6,180 working-class dwelling houses were found to be unoccupied, as were 85 shops and 11 public houses. In addition, the occupiers of nearly 3,000 other dwelling houses did not pay the poor rate; upon examining 1,950 of the defaulters, the board of guardians excused 1,134 (58 percent) of them on the grounds of poverty. Most seriously, twelve of the town's forty factories had shut down, and could not pay their assessment. Under the circumstances, local officials surmised that another increase in the poor rate would cause more ratepayers to default and would yield little additional tax revenue. ${ }^{6}$

The Role of Charity in the Depression 0/1841-1842 The inability of the Poor Law to support all who needed assistance during serious downturns led to large-scale charitable efforts to assist the poor. In Manchester in 1841/42, local charitable organizations set up soup kitchens and provided bedding, clothing, and coal to the poor. In Stockport in 1841, a committee composed of the mayor, clergymen, magistrates, and "leading manufacturers" was appointed to "inquire into the state of the poor and unemployed . . . and to suggest means for their relief." Two months later, the committee reported that, although the poor rate had doubled, "it is impossible to collect sufficient [funds] to meet the current expen-

6 Details are not available for the November 1841 assessment. The precise timing of assessments is difficult to explain, since it was determined, in part, by unforeseen increases in relief expenditures. However, boards of guardians also might have felt that during downturns two or three small assessments a year was less of a burden on taxpayers than one large assessment. Parliamentary Papers, State of the Population of Stockport (1842, XXXV), 213-216. 
Table 2 Poor-Rate Returns for Stockport, October 1836-June 1841

\begin{tabular}{|c|c|c|c|c|c|c|c|c|c|}
\hline & AMOUNT & & & & TOTAL & AMOUNT & SHARE OF & & AMOUNT NOT \\
\hline DATE WHEN & IN THE & RATEABLE & & ARREARS & AMOUNT TO & ACTUALLY & POOR RATE & PRESENT & RECOVERABLE \\
\hline ASSESSED & POUND & VALUE & RATE & DUE & BE COLLECTED & COLLECTED & COLLECTED & ARREARS & OR EXCUSED \\
\hline Oct. 1836 & 15. $3 d$. & $£ 65,375.3$ & $£ 4,086.0$ & $£ 811.0$ & $£ 4,896.9$ & $£ 3,745.1$ & 0.917 & $£ 494.3$ & 657.5 \\
\hline July 1837 & is. $\quad g d$. & $66,015.3$ & $5,776.3$ & 494.3 & $6,270.6$ & 4,745-6 & 0.822 & 648.2 & 876.8 \\
\hline May 1838 & $05.6 d$. & $66,067.8$ & $1,651.7$ & 648.2 & $2,299.9$ & $1,310.1$ & 0.793 & 700.3 & 289.5 \\
\hline Oct. 1838 & 25. od. & $66,098.3$ & $6,609.6$ & 700.3 & $7,309.9$ & $4,787.3$ & 0.724 & 772.7 & $1,749-9$ \\
\hline Nov. 1839 & 15. $6 d$ & $65,950.8$ & $4,946.3$ & 772.7 & $5,719.0$ & 3,2454 & O.656 & $1,239.1$ & $1,234-5$ \\
\hline July 1840 & 25. od. & $65,515.0$ & $6,551-5$ & $1,239.1$ & $7,790.6$ & $4,446.8$ & 0.679 & $1,848.4$ & $1,495-4$ \\
\hline Feb. 1841 & is. od. & $64,527.3$ & $3,226.4$ & $1,848.4$ & $5,074.8$ & $1,837.3$ & 0.569 & $2,646.2$ & 591.3 \\
\hline June 1841 & is. od. & $63,184.0$ & $3,159.2$ & $2,646.2$ & $5,805.4$ & $2,195.4$ & 0.695 & $2,494-5$ & $1,115.5$ \\
\hline
\end{tabular}

SOURCE Parliamentary Papers, Report of the Assistant Poor Law Commissioners . . on the State of the Population of Stockport (1842, XXXV), 279. 
diture, and as small as the relief afforded is, . . it is more than the resources of the rate-payers, if unaided, will continue to afford." The committee appealed to the public for donations, raising nearly $£ 3,000$ from private contributions and relieving, on average, 3,350 families at an average cost of $£ 34^{\circ}$ per week for two months. By comparison, during the two-year period from Ladyday (March 25) 1841 to Lady-day 1843, the Stockport union spent $£ 40,670$ on poor relief, or about $£ 390$ per week. Most of the money raised by the Stockport relief committee had been donated by "the wealthier inhabitants of the borough and those resident in the neighbourhood." 7

Stockport's need to appeal for private charity to assist the unemployed reveals the inadequate nature of the poor-rate assessment system, which did not effectively tap the new wealth created by industrialization. In response to the increase in the number of relief applicants, three poor rates were levied in 1841-all of them inadequate to relieve the large number of unemployed workers but large enough to be "a serious drain upon the diminished resources of the comparatively few [individuals and firms] . . . able to pay them." Rather than levying another poor rate, which would have resulted in even more defaults, Stockport set up a relief committee in the fall of 1841 to raise funds privately. A significant share of the charitable contributions must have been made by mill owners and merchants, two groups whose wealth was relatively lightly taxed under the poor-rate assessment system. This approach was an inefficient way to tap the resources of the industrial elite; cities had no authority to compel manufacturers or merchants to make large contributions to the relief funds. Yet, cities were forced to proceed in this manner because of the nature of the poor rate. ${ }^{8}$

Not all charitable relief was raised locally. In its report of 1841, the Stockport relief committee stated that, because of the great amount of distress among the unemployed, it was "fully convinced that all the efforts that can possibly be made in the town

7 Joseph Adshead, Distress in Manchester: Evidence of the State of the Labouring Classes in 1840 42 (London, 1842), 40-41; Parliamentary Papers, State of the Population otStockport (1842, XXXV), 283, 233-234; Parliamentary Papers, Average Annual Expenditure of Parishes in Unions in England and Wales \&c. (1844, XL).

8 Rose, "Administration of Poor Relief," 348-350; Parliamentary Papers, State of the Population of Stockport (1842, XXXV), 285. 
and neighbourhood will be utterly inadequate to meet the pressing necessities of the case." It therefore appealed for assistance "to those individuals and classes of society who feel little of the pressure of the times." In response to similar appeals from several cities, the home secretary set up the London Manufacturers' Relief Committee in the spring of 1842 "to co-ordinate and regulate the distribution . . . of charitable funds . . . raised in England to relieve industrial distress." The committee contained sixty members, including the archbishops of Canterbury and York. It received slightly more than $-£ 100,000$ in donations. Three-quarters of the funds raised were in response to a letter from Queen Victoria, which was read in English churches in July, appealing for aid for the unemployed. The other $£ 24,600$ was raised by subscription, presumably from wealthy individuals. The committee granted relief to localities that requested it, provided that they had already organized a local committee consisting of "magistrates, clergy, and principle inhabitants," and that local subscriptions had already been raised for relief of the poor. The committee required that the major part of the relief be granted to able-bodied men and their families, that at least one-half of the relief be given in kind, and that work be required from able-bodied men in return for relief. It made a grant of $£ 500$ to the Stockport relief committee. ${ }^{9}$

Poor Relief and Charity during the Downturns 0/1847/48 and 1858 The downturns of $1847 / 48$ and 1858 were not as severe as the depression of 1841/42, although some cities experienced high unemployment, especially in 1847/48. Unemployment in Manchester cotton mills during the first six months of 1848 averaged 18.6 percent, and another 9.5 percent of factory workers were on short time. Numbers receiving poor relief, and relief expenditures, increased sharply in 1847/48. From the winter of $1845 / 46$ to the winter of $1847 / 48$, the number of relief recipients more than tripled in Manchester and nearly doubled in Bradford. During the same period, relief expenditures increased by 86 percent in Man-

9 Parliamentary Papers, State of the Population of Stockport (1842, XXXV), 217; Smout, "Strange Intervention of Edward Twistleton," 253; Parliamentary Papers, Report from the Select Committee on Distress (Paisley) (1843, VII), 3-4. The recipient of the most aid from the London relief committee was the Scottish city of Paisley, which was granted ^15,081 between May 1842 and February 1843, due to the severity of its depression and the fact that under the Scottish Poor Law, able-bodied workers were not eligible for poor relief even when unemployed. See Smout, "Strange Intervention of Edward Twistleton;" R. A. Cage, The Scottish Poor Law 1745-1845 (Edinburgh, 1981), 10-15. 
Chester, 121 percent in Bradford, and 78 percent in Leeds. That the downturn of 1858 is barely perceptible in the Poor Law statistics - the total number of relief recipients in England and Wales increasing by less than 3 percent from 1857 to 1858 -is not surprising, given that it was shorter and less severe than either of the slumps of the $1840 \mathrm{~s}^{10}$

The extent of charitable assistance for the unemployed during the $1847 / 48$ and 1858 downturns is more difficult to measure. Manchester charities raised approximately $£ 19,000$ in 1848 from subscriptions, donations, collections, etc., but how much of this money went to aid the unemployed is not clear. In Leeds, the unemployed received assistance from the Benevolent or Strangers' Friend Society and from an ad hoc relief fund. The contribution from private charity from 1847 to 1849 was much smaller than it had been in 1842; the relief funds collected in 1847 and 1849, combined, totaled $£ 3,500$, half of the amount collected in 1842 . A soup kitchen relieved 15,000 persons in April 1848. There is little evidence of large-scale charitable relief funds during the 1858 downturn. Glasgow, which provided assistance to 10,051 families during the winter of $1857 / 58$, may have had the largest emergency fund. ${ }^{11}$

The downturns of $1847 / 78$ and 1858 did not create widespread relief crises as the $1841 / 42$ depression had done. In most cities, emergency charitable funds were unnecessary because the Poor Law was able to handle relief of the unemployed. However, the government did nothing during this period to fix the defects of

10 Unemployment data were obtained from The Economist, weekly issues from January 8 to July i, 1848. See also Sidney Pollard, "Labour in Great Britain," in Peter Mathias and Michael M. Postan (eds.), The Cambridge Economic History of Europe. VII. The Industrial Economies: Capi tal, Labour, and Enterprise (Cambridge, 1978), 126-127. Data about the number of relief recipients for the half-year ending Lady Day (March 25) are from Parliamentary Papers, Return of the Comparative Expenditure for the Relief of the Poor, [and the Comparative Number of Poor Relieved, . . . in the Six Months ending Lady day in 1846, 1847, and 1848 (1847/48, LIII), 185. Data about relief expenditures are from Boyer, An Economic History of the English Poor Law, 17501850 (Cambridge, 1990), 238; Karel Williams, From Pauperism to Poverty (London, 1981), 158.

11 Peter Shapely, Charity and Power in Victorian Manchester (Manchester, 2000), 38, gives the sources of income for nine Manchester charities in 1848. Kidd, "Charity Organization," 47 48, contends that the activities of Manchester charities-the Manchester and Salford District Provident Society in particular-declined in the 1840s and 1850s. Robert Morris, Class, Sect, and Party: The Making of the British Middle Class, Leeds 18201850 (Manchester, 1990), 302-303; John F. C. Harrison, Early Victorian Britain, 1832-51 (London, 1988), 57; Beveridge, Unemployment, 66. 
the poor-rate assessment system, bringing the problems associated with the Poor Law to a head in Lancashire cities a few years later.

Poor Relief and Charity during the Lancashire Cotton Famine

During the American Civil War of 1861 to 1865, raw cotton imports to Britain declined sharply, forcing Lancashire cotton factories to curtail production severely or shut down. At the peak of the cotton famine, in December 1862, 266,500 persons were receiving poor relief in twenty-three distressed Poor Law unions, out of a population of $1,870,600$. An additional 200,000 to 236,000 persons received relief from charitable funds. In total, 25 to 27 percent of the population of the distressed region obtained help through either public or private sources. In several Poor Law unions, more than one-third of the population must have received some form of assistance at the peak of the famine. Some of the persons receiving poor relief also benefited simultaneously from charitable funds; the total number of persons receiving relief from charitable funds during the winter of 1862/63 was almost certainly more than 300,000 and possibly more than $350,000 .{ }^{12}$

In the early months of the famine, numbers on relief increased rapidly in several Poor Law unions, and the relief roles continued to grow throughout the summer and fall of 1862 (see Table 3). As had occurred in 1842, the increased demand for relief and the large number of defaults on poor-rate assessments caused several Poor Law unions to run into serious financial problems. Blackburn, Rochdale, Preston, and Ashton formed private-relief committees early in 1862, and most of the other towns in the distressed area soon followed suit. ${ }^{13}$

In the spring of 1862, Lancashire officials began to appeal to the rest of Britain for help. A group of London merchants associated with the cotton industry convinced the Lord Mayor of London to form the Lancashire and Cheshire Operatives Relief Fund (or Mansion House Fund). From May 1862 to June 1865, the fund contributed $£ 528,336$ to the distressed cotton districts. Another relief fund, the Bridge water Fund, emerged in London, eventually

12 John Watts, The Facts of the Cotton Famine (London, 1866), 120; R. Arthur Arnold, The History of the Cotton Famine (London, 1865), 191. The central relief committee of Manchester estimated that in January $1863,235,741$ persons were relieved by private relief committees only, and that an additional 138,889 were relieved both by the Poor Law guardians and the local committees-the total number of persons receiving private relief being 374,630 (cited in the Journal of the Statistical Society of London, XXVII [1864], 600).

13 William O. Henderson, The Lancashire Cotton Famine 1861-1865 (Manchester, 1934), 74. 
Table 3 Percentage of Population Receiving Poor Relief in Ten Distressed Poor-Law Unions during the Cotton Famine, September 1861-November 1862

PERCENTAGE OF POPULATION RECEIVING POOR RELIEF

\begin{tabular}{|c|c|c|c|c|c|c|}
\hline POOR LAW UNION & $\begin{array}{c}\text { SEPTEMBER } \\
1861\end{array}$ & $\begin{array}{c}\text { FEBRUARY } \\
1862\end{array}$ & $\begin{array}{r}\text { JUNE } \\
1862\end{array}$ & $\begin{array}{c}\text { SEPTEMBER } \\
1862\end{array}$ & $\begin{array}{c}\text { NOVEMBER } \\
1862\end{array}$ & $\begin{array}{r}\text { NUM BER ON } \\
\text { SEPT. ][86I-JU }\end{array}$ \\
\hline Ashton-under-Lyne & 1.3 & 34 & $7-1$ & 15.2 & 25.6 & 443.6 \\
\hline Blackburn & 2.3 & $7-7$ & 9.6 & H.7 & 20.0 & 313.3 \\
\hline Burnley & 1.8 & $3-3$ & $4-5$ & 8.8 & II. 2 & H3. 3 \\
\hline Bury & i-9 & $3-7$ & $3-8$ & 7.6 & II. 7 & 98.4 \\
\hline Manchester & $3-4$ & 6.4 & $7-7$ & II. 7 & 21.1 & 125.7 \\
\hline Oldham & 1.6 & 2.6 & 2.8 & 6.5 & 14.2 & $73-3$ \\
\hline Preston & 2.9 & 10.5 & 11.0 & $15-3$ & 21.0 & 275.7 \\
\hline Rochdale & 2.2 & 4.5 & 4.8 & 9.8 & 15.2 & 120.2 \\
\hline Salford & 2.5 & 4.1 & 44 & 6.4 & IO.9 & 794 \\
\hline Stockport & 1.6 & 4.8 & 6.4 & 10.2 & 13.0 & 306.1 \\
\hline
\end{tabular}

SOURCES Data on the number of relief recipients are from Parliamentary Papers, Return of the Number of Paupers... in Receipt of Relief in Each Week of the Four teen Months Ending with December 1858, 1861, and 1862, Respectively (1862, XLIX, Pt. 1), 122-177; Parliamentary Papers, Return ... and Summary of the Number of Paupers Relieved . . . in Each Week of the Twenty two Months Ending with August 1863 (1863, LII), 182-192. 
raising $£ 52,000$ for the relief of Lancashire. Soon after the initiation of the Mansion House Fund, the (Manchester) Central Relief Committee was formally established; it included the mayors and ex-mayors of the principal towns of the cotton district and a number of gentlemen associated with the commercial interests of Manchester. One of its first acts was to draft a resolution directed at city and county officials throughout Britain, requesting aid for the families of distressed workers connected with the cotton trade. The money raised by the two London relief committees went to either the Central Relief Committee in Manchester or the individual local committees for distribution. ${ }^{14}$

The total amount expended by public and private sources for poor relief in Lancashire from March 1861 to March 1864 was about $£ 3,530,400$. Poor-relief expenditures equaled $£ 1,937,920$, or 54.9 percent of the total; charity accounted for the remaining 45.1 percent. Of the charitable funds raised, £786,400 (22.3 percent) came from the cotton districts; the remaining $£ 806,000$ came from elsewhere in Britain or overseas. Altogether, slightly more than three-quarters of expenditures came from local sources. If manufacturers and other large employers of labor paid 40 percent of the poor rate, and contributed half of the charitable funds raised within the distressed area, they would have paid one-third of the amount spent on public and private relief during the famine. In addition to their contributions to charitable funds, some manufacturers "gave their 'hands' daily meals and established soup kitchens," and those who owned cottages in which their workers lived generally did not collect rent during the famine. Manufacturers paid, at most, 40 percent of the cost of relieving the unemployed, even counting the value of rents excused and meals given to workers. $^{15}$

There was some friction between the authorities in the cotton districts and the London relief committees, as well as between the central executive committee in Manchester and the local boards of guardians and relief committees. The administrators of

14 Watts, Facts of the Cotton Famine, 160-161; Henderson, Lancashire Cotton Famine, 79; Arnold, History of the Cotton Famine, 82-83.

15 Thomas MacKay, A History of the English Poor Law (London, 1899), III, 416. The charitable contributions from the cotton district included $£ 289,000$ raised by the local relief committees, $£ 276,500$ raised by the central relief committee of Lancashire or the London relief committees, and $£ 220,000$ locally distributed outside of the local committees and the central committee. Arnold, History of the Cotton Famine, i n. 
the London committees, anxious that the funds that they raised should "relieve the destitute and not the ratepayers," complained that the local boards of guardians were not spending enough on poor relief. Before making a grant to a local relief committee, the central executive committee required information about the locality's expenditures on poor relief, the amount of charitable funds collected by the local committee, the number of unemployed operatives in the town, the number relieved by the guardians and the local committee, and the generosity of public and private relief $^{16}$

In the summer of 1862, when the resources of both the local boards of guardians and the relief committees began to be strained, Parliament intervened to ease the financial burdens of the distressed areas. The Union Relief Aid Act of 1862 had three major provisions. First, if the poor rate of any parish in the distressed area exceeded 35. in the pound, the excess should be charged to the other parishes in the Poor Law union. Second, if the aggregate poor rate for a union exceeded 55. in the pound, the Poor Law Board could order other unions in the county to contribute money to meet the excess. Third, if the aggregate rate for a union exceeded 35. in the pound, it could apply to the Poor Law Board to borrow the excess, to be repaid within seven years. The first provision effectively shifted part of the cost of relieving the unemployed from working-class parishes to wealthier parishes in the same Poor Law union. ${ }^{17}$

In 1863, Parliament adopted a second law to aid the distressed areas-the Public Works (Manufacturing Districts) Bill-which allowed local boards of guardians to borrow money from the national government for thirty years at an interest rate of 3.5 percent. The money was to be used for public-works projects using the labor of unemployed cotton operatives, who were to be hired

16 Arnold, History of the Cotton Famine, 150-152; Watts, Facts of the Cotton Famine, 190; Henderson, Lancashire Cotton Famine, 76-77.

17 MacKay, English Poor Law, 395-396. The extent of this cost shift to wealthier parishes was large in some unions. For the half-year ending Lady Day 1863, in Ashton-under-Lyne, $82.9 \%$ of relief expenditures were charged to the union common fund, and only $17.1 \%$ to the individual parishes. In Stockport, Rochdale, Preston and Blackburn, two-thirds or more of relief expenditures were charged to the union (Parliamentary Papers, Sixteenth Annual Report of the Poor Law Board, 1863-64 [1864, XXXV], 330). The principle of shifting the responsibility for paupers from the parish to the Poor Law union was made permanent in 1865. See Mary MacKinnon, "English Poor Law Policy and the Crusade against Outrelief," Journal of Economic History, XLVII (1987), 603-625. Watts, Facts of the Cotton Famine, 291-293. 
to do unskilled manual labor and paid the going wage for unskilled workers. From 1863 to 1865 , ninety local authorities borrowed $£ 1.85$ million to construct public works. Although many beneficial projects were undertaken, the Act was a failure as an employment project. Rather than create so many as 30,000 jobs for unemployed operatives, as its sponsors expected, peak employment on public works was 6,424 in October 1864, only 4,990 of whom were cotton operatives. ${ }^{18}$

From 1834 to 1865 , unemployment relief was financed by a combination of public and private sources. The Poor Law usually proved capable of relieving the unemployed. During major downturns, however, voluntary organizations had to raise money, and localities sometimes had to appeal elsewhere for help-as in 1842 and 1862, when national charities were established to solicit funds throughout England for the support of unemployed workers in industrial cities.

Generosity of Relief, 1834-1870 Throughout this period, boards of guardians and relief committees tried to set the generosity of relief benefits at a level high enough to ensure that unemployed workers and their families would be able to subsist in good health, but low enough that the incentive to work would not be lost. The level of benefits given to an unemployed worker was determined by family size and by the income, if any, that other family members were earning. Benefit levels were remarkably similar across towns and over time; guardians typically granted 25 . to 35 . to a single adult male per week, and $15.6 d$. to 25 . $6 d$. per week for each additional family member. The benefits were smaller if the applicant's family had other sources of income. For example, in 1841, Bolton guardians granted applicants enough relief to make up their income "to $2 \mathrm{~s}$. 3d. per head per week . . . where we clearly ascertain the amount [the family] earned."19

18 MacKay, English Poor Law, 398-404; Henderson, Lancashire Cotton Famine, 61-63. The public works undertaken in 1863-1865 were not criticized for their "pauperizing" effects on workers nearly so strongly as were later work-relief projects. Robert Rawlinson, admittedly not a neutral observer, wrote that the workers' conduct was "exceedingly good." However, Charles Trevelyan concluded that the mixing of labor and charity associated with the publicworks projects engendered "great abuse and demoralisation" (quotations from Henderson, Lancashire Cotton Famine, 63, 66).

19 Rose, "Administration of Poor Relief," 195-196; Parliamentary Papers, A Copy of Reports Received by the PoorLaw Commissioners in 1841, on the State of the Macclesfield and Bolton Un ions (1846, XXXVI), 12-13. 
When downturns became exceptionally severe, boards of guardians or relief committees often were forced by lack of funds to reduce relief generosity. During the cotton famine, officials who typically tried to maintain relief benefits at about 25 . per person per week were forced to reduce benefits to less than 15 . $6 d$. per person. The guardians realized that the relief that they were granting was inadequate and "assumed that this meagre sum would be augmented from other sources," including charitable aid. Their assumption appears to have been correct. An estimate of 1863 suggests that over 60 percent of individuals receiving outdoor relief from the guardians also received assistance from the local committees. In combination, poor relief and private charity were able to maintain the generosity of relief at about its pre-famine level. George Buchanan reported at the peak of distress in 1862 that "taking the great mass of the cotton workers with their families as a whole, their average income . . . from all sources is nearly $2 \mathrm{~s}$. per head per week. This is exclusive of clothing, bedding and firing which are now usually supplied in addition." ${ }^{20}$

Modern studies of relief generosity tend to focus on the relationship between benefits and wages. During the cotton famine, the central executive committee in Manchester strove to maintain an average benefit/wage ratio of about one-third. However, because an unemployed individual's benefits were tied to the size of his family rather than to his wage, the benefit/wage ratio tended to vary. If applicants for assistance in both periods received 25. per family member per week in public and private relief, an unemployed class 3 spinner with a wife and two children would have had a benefit/wage ratio of 48.5 percent in $1841 / 42$. For a class 1 spinner, the benefit/wage ratio would have been 20 percent. In $1862 / 63$, an unemployed class 3 spinner from a family of four

20 L. Lynne Kiesling, "Institutional Choice Matters: The Poor Law and Implicit Labor Contracts in Victorian Lancashire," Explorations in Economic History, XXXIII (1996), 83; Rose, "Rochdale Man and the Stalybridge Riot: The Relief and Control of the Unemployed during the Lancashire Cotton Famine," in A. P. Donajgrodzki (ed.), Social Control in Nineteenth Century Britain (London, 1977), 189; Journal of the Statistical Society of London, XXVII (1864), 600. The Buchanan quotation is from Henderson, Lancashire Cotton Famine, 99. The Manual for the Guidance of Local Relief Committees in the Cotton Districts Arising out of the Experience of 1862-63 stated, "The Scale of Relief which has obtained the approval of the Central Executive Committee is one which provides, on the average, two shillings per head for the whole mass of recipients; to which may be added, in winter, supply of fuel and clothing, if the family have been long out of work" (Henderson, Lancashire Cotton Famine, 100). 
would have had a replacement rate of 37 percent; for a class 1 spinner, the replacement rate was 20 percent. $^{21}$

The Crisis of the 1860s in London The Lancashire cotton famine was not the only poor relief crisis of the 1860s. Rose contends that during the decade, "the English poor relief system was subjected to an almost continual series of shocks which exposed its basic weakness." London was especially hard hit. In the winter of 1860/61, the Thames froze, causing a decline in all outdoor work and the complete cessation of riverside employment for several weeks. The resulting flood of applications for relief created severe problems in several east London Poor Law unions. As in the northern industrial cities, the poor-relief crisis led to a large increase in private charitable expenditures-approximately $£ 40,000$ being raised by various charities. ${ }^{22}$

The London Poor Law suffered an even larger shock from 1866 to 1869 , when the combination of a business-cycle downturn, the decline of the London shipbuilding industry, and severe winter weather greatly increased the demand for poor relief. Once again, the East End suffered the worst blow. In Poplar, the number of paupers relieved in late December $1867^{\text {was }} 78$ percent greater than the number relieved at the same time in 1865 . The strain on the East End Poor Law Unions was enormous. Most middle-class ratepayers already had moved out of the area, driving down the tax base. As a result, poor rates were high even during normal years; in the late $1860 \mathrm{~s}$, they increased to more than 3.55 . in the pound in Bethnal Green, Stepney, and elsewhere. In several East End districts, as many as one-third of taxpayers were unable to pay their poor rates. Local guardians were forced to turn to private charities for assistance. Charitable aid poured in from London's wealthier districts. The indiscriminate nature of charitable relief

21 Rose, "Rochdale Man," 191. In 1841, the average weekly wage of Lancashire cotton spinners was 21s. $8 d$; wages ranged from 405 . for a class 1 spinner to 165 . $6 d$. for a class 3 spinner. In 1861 , the average wage of cotton spinners was $24 \mathrm{~s} .4^{\wedge}$.; wages ranged from 395 . $6 d$. for a class 1 spinner to 21s. $6 d$. for a class 3 spinner. Wage data are from George $\mathrm{H}$. Wood, The History of Wages in the Cotton Trade during the Past Hundred Years (London, 1910), 28.

22 Rose, "Crisis of Poor Relief," 54. An east London minister wrote in late January 1861, "the history of the last month shows that the Poor Law has broken down, that it is utterly incompetent under its present constitution to relieve the London poor" (David R. Green, From Artisans to Paupers: Economic Change and Poverty in London, lygo-iSyo [Aldershot, 1995], 234). For a description of east London's poor in January 1861, see John Hollingshead, Ragged London in 1861 (London, 1861), 39-97. Beveridge, Unemployment, 157. 
appalled many middle-class observers. John R. Green, a vicar in Stepny, wrote in 1868 that "some half a million of people in the East End of London have been flung into the crucible of public benevolence, and have come out of it simply paupers. . . . The very clergy who were foremost in the work of relief last year stand aghast at the pauper Frankenstein they have created." ${ }^{23}$

The breakdown of the Poor Law in the 1860s, together with the unsystematic nature of charitable aid, convinced many that the system of poor relief required a "radical restructuring" to restrict the provision of outdoor relief and to regulate the provision of private charity severely, thus to restore self-help among the poor. In the decade that followed, major changes in the Poor Law significantly altered the form of public assistance for unemployed workers.

\section{UNEMPLOYMENT RELIEF, 187 O-I9II}

The Crusade Against Outrelief The early 1870s represent a watershed in the history of unemployment relief. Encouraged by the newly formed Local Government Board (LGB), Poor Law unions throughout England and Wales sharply limited outdoor relief for all types of paupers - in particular, able-bodied males. This change in policy, known as the Crusade Against Outrelief, was a joint consequence of the Poor Law crisis of the 1860s, a change in middle-class attitudes toward poverty, and new methods to finance the Poor Law. ${ }^{24}$

In the aftermath of east London's Poor Law crisis from 1866 to 1869 , George Goschen, President of the Poor Law Board, issued a Minute to Poor Law officials in the metropolis, criticizing the granting of outdoor relief to the able-bodied and calling for greater coordination of relief efforts between the Poor Law and private charity. Two years later, the LGB issued a circular stating that the increase in expenditures on outdoor relief during the 1860 s was "so great, as to excite apprehension," and concluded

23 Green, From Artisans to Paupers, 235, 231-241; Jones, Outcast London, 249-251. J. R. Green's quotation is given in Helen Bonsanquet, Social Work in London, 1869-1912: A History of the Charity Organisation Society (London, 1914), 13-14.

24 The Crusade Against Outrelief is discussed in MacKinnon, "English Poor Law Policy"; Robert Humphreys, Sin, Organized Charity and the Poor Law in Victorian England (New York, 1995)- 
that generous outdoor relief was destroying self-reliance among the poor. In the circular's words, "a certainty of obtaining outdoor relief in his own home whenever he may ask for it extinguishes in the mind of the labourer all motive for husbanding his resources, and induces him to rely exclusively upon the rates instead of upon his own savings for such relief as he may require." ${ }^{25}$

The government was not alone in its condemnation of generous poor relief. Beatrice Webb wrote that during the 1860 s and 1870 s, the upper classes became obsessed that "the mass-misery of great cities arose mainly, if not entirely, from spasmodic, indiscriminate and unconditional doles, whether in the form of alms or in that of Poor Law relief." Mid-Victorian Britain saw the rise of an ethic of respectability and self-help, preached by such middleclass reformers as Smiles, who wrote that working men could be independent if they practiced industry and thrift; it was "the duty of the prudent man" to set aside money to provide for unemployment and sickness. Smiles' views were echoed by the Charity Organization Society (cos), founded in 1869, partly in response to the indiscriminate nature of Londoners' recent charitable giving. The cos maintained that even most low-skilled workers earned enough to set aside income in anticipation of future interruptions in earnings. The failure of workers to save was caused, to a large extent, by the easy availability of generous outdoor relief; thus would the restriction of outdoor relief improve the moral and economic condition of the poor in the long run. Unregulated charity had a similar effect on the poor. An early leader of the cos wrote that "indiscriminate charity is one of the curses of London. . . . The effect of this charity is that. . . the people never learn to work or to save." ${ }^{26}$

The third catalyst of the Crusade Against Outrelief was Parliament's passage of the Union Chargeability Act in 1865, and similar acts relating to London in 1867, 1869, and 1870. The Union Chargeability Act placed the entire cost of poor relief on the Poor Law union rather than on each parish within it. The adoption of

25 The texts of Goschen's 1869 Minute and the LGB'S 1871 Circular can be found in Rose, The English Poor Law, 1780-igjo (Newton Abbot, 1971), 226-230.

26 Beatrice Webb, My Apprenticeship (London, 1926), 200; Samuel Smiles, Self-Help: With Illustrations of Character, Conduct, and Perseverance (Oxford, 2002; orig. pub. 1866), 242-260; MacKinnon, "English Poor Law Policy," 606-607; Henrietta Barnett, Canon Barnett, His Life, Works, and Friends (London, 1919), I, 83. 
union rating shifted a large share of the cost of relief from working-class parishes (which had many paupers and a low tax base) to middle-class parishes (which had fewer paupers and a higher tax base). The infusion of money from wealthier parishes eased the financial burdens that had plagued the Poor Law, and enabled unions to construct new, and larger, workhouses. The tax-rate increase in the wealthier parishes also sparked a reconsideration of poor relief. Boards of guardians typically were dominated by members from the wealthier parishes, who responded to the increase in their taxes by looking for ways to reduce the cost of relief. Their search led them to the cos, which claimed that since the vast majority of applicants for relief would refuse to enter workhouses, a shift from outdoor relief to relief in workhouses would significantly reduce relief expenditures. ${ }^{27}$

Boards of guardians throughout England accepted the cos' claims that the restriction of outdoor relief would both improve the morality of the poor and reduce the cost of relief. Webb wrote that behind the cos' "array of inductive and deductive proof of the disastrous effect on the wage-earning class of any kind of subvention, there lay the subconscious bias of'the Haves' against taxing themselves for 'the Have Nots.'" Thus, "it is not surprising that the . . . tenets of the originators of the idea of charity organisation found ready acceptance among the enlightened members of the propertied class." 28

One of the aims of the Crusade Against Outrelief was to make reliance on the Poor Law during times of "personal distress" an unpalatable option for workers. In this regard, it was a great success. Workers who once viewed outdoor relief as a right began to attach a strong stigma to entering workhouses. The share of the population receiving poor relief declined almost continuously from 1870 to 1913. Skilled workers largely accepted the Victorian ethic of self-help, protecting themselves against income loss by saving money and by joining trade unions and friendly societies. Trade unions became a major source of unemployment benefits for skilled workers, who became much less likely to turn to local authorities or charitable institutions for assistance. On the other

27 Expenditures on workhouse construction increased sharply after the adoption of the Union Chargeability Act. See Williams, From Pauperism to Poverty, 218-219. MacKinnon, "English Poor Law Policy," 607-608.

28 Webb, My Apprenticeship, 201. 
hand, unemployed low-skilled workers continued to rely on public and private assistance, but typically not poor relief. Proper study of unemployment relief during this period requires looking at skilled and unskilled workers separately.

Trade Union Unemployment Benefits Although certain craft unions had started to provide their members with "friendly benefits" early in the nineteenth century, the adoption of mutual insurance policies increased sharply during the third quarter of the century. Unemployment benefits were the most important of the union benefits, because they represented "a service which must, in their absence, remain unperformed." Private mutual-help associations, known as friendly societies, offered sickness, old-age, and funeral benefits, but not unemployment insurance. Workers anxious to insure themselves against unemployment could do so only through a trade union. ${ }^{29}$

In $1893,744,000$ trade union members (59 percent of the total) were eligible for unemployment benefits; by 1908, 1,474,000 workers were eligible for them-66 percent of all union members but only 12 percent of the adult male workforce. The availability and duration of unemployment benefits differed markedly by occupation. In 1911, virtually all union members in the metal, engineering, shipbuilding, and printing trades were entitled to unemployment benefits, compared with 67 percent in the building trades, 59 percent in cotton, 38 percent in mining, and only 5 percent in laborers' unions. ${ }^{30}$

29 Webb and Webb, Industrial Democracy (London, 1897), 160-161. In 1901, 4.14 million persons belonged to friendly societies providing sickness insurance. See Johnson, Saving and Spending, 57. However, only 28,000 persons belonged to societies providing unemployment insurance (Harris, Unemployment and Politics, 295). For an explanation of why friendly societies did not offer unemployment insurance, see Boyer, "What Did Unions Do in Nineteenth Century Britain?" Journal of Economic History, XLVIII (1988), 319-332.

30 Data for 1893 are from Board of Trade, Seventh Annual Report on Trade Unions (London, 1895). Data for 1908 are from Board of Trade, Report on Trade Unions in 1908-10 (London, 1912). Data on union membership and the adult male workforce in 1908 are from George S.

Bain and Robert Price, Profiles of Union Growth: A Comparative Statistical Portrait of Eight Coun tries (Oxford, 1980), 37. In mining and cotton, the numbers cited are for the share of workers entitled to benefits because of "bad trade" or mill stoppages; a larger percentage of workers were eligible for benefits if they were unemployed due to fires, breakdowns of machinery, etc. Unemployment benefits largely were unnecessary in coal mining and cotton textiles because of the widespread use of short time and sliding wage scales, which resulted in relatively few layoffs during cyclical downturns. Unions of low-skilled workers did not provide unemployment benefits because the irregularity of employment in most low-skilled occupations raised the cost of insurance substantially above the weekly premium paid by skilled workers 
Union-provided unemployment insurance was financed by members' weekly contributions. The typical union member paid $6 d$. to 15. per week in dues. Although no unions maintained separate unemployment insurance funds, it is possible to estimate the cost of unemployment insurance by calculating individual unions' average annual expenditure per member on unemployment benefits. Such a calculation for three major unions-the Amalgamated Society of Engineers, the Amalgamated Carpenters and Joiners, and the London Compositors-from 1870 to 1896 yields average annual expenditures on unemployment benefits per member of 22.35., 15.35., and 16.45., respectively, or 3.5^. to 5.id. per member per week. Adding a small amount for administrative costs brings the cost to insure a skilled worker against unemployment to $\backslash d$. to $6 d$. per week, which was 1 to 2 percent of his weekly income. ${ }^{31}$

The Board of Trade reported the total expenditures on unemployment benefits of 100 principal trade unions for the years 1892 to 1910. Annual expenditures varied from a low of ^ 184,600 in 1899 to a high of $£ 1,004,685$ in 1908; the average annual expenditure was $£ 468,500$. The Labour Department estimated that all trade unions in Britain spent a total of $£ 1,257,913$ on unemployment benefits in 1908. In other words, the 100 principal unions accounted for 80 percent of the total expenditure. If that ratio held throughout the period from 1892 to 1910, the average annual expenditure on unemployment benefits by all trade unions amounted to $£ 585,600$. $^{3}$

The generosity and the maximum duration of unemployment benefits differed significantly from union to union. In 1892, the average weekly benefit was about 105 . per week, at least for the first twelve to fourteen weeks of unemployment. The Amalgamated Engineers paid an unemployed member 105. per week for the first fourteen weeks of unemployment, then 75 . per week for the next thirty weeks, and $6 s$. per week for another sixty weeks.

and above what the unskilled could afford to pay. See Boyer, "What Did Unions Do?" 324 328; Beveridge, Unemployment, 220-1; J. H. Porter, "Wage Bargaining under Conciliation Agreements, 1860-1914," Economic History Review, XXIII (1970), 466- 475.

31 Data on trade unions' annual expenditures per worker on unemployment benefits are from George H. Wood, "Trade Union Expenditure on Unemployment Benefits since i860," 
The Amalgamated Carpenters and Joiners paid ios. a week for the first twelve weeks of unemployment and then $6 s$. a week for the next twelve weeks. The maximum duration of benefits was twenty-four weeks. The Amalgamated Smiths and Strikers paid 65. per week for a maximum of eight weeks. ${ }^{33}$

Aggregate data on generosity and duration of unemployment benefits for 1908 are presented in Table 4. The maximum weekly benefit was between 95 . 3d. and 105 . for 42 percent of workers, and between $85.3 \mathrm{~d}$. and 105 . for 55 percent of workers. On average, weekly unemployment benefits in 1908 were about equal to their level in 1892. The maximum duration of benefits varied widely-fifty-two weeks or longer for 48 percent of workers in metals and 41 percent of workers in mining, but only nineteen to twenty-five weeks for the majority of workers in the building trades, and thirteen weeks or less for the majority of workers in textiles.

The maximum replacement rate for carpenters was, on average, 29 percent in 1892 and 26 percent in 1908. For fitters, the maximum replacement rate was, on average, 30 percent in 1892 and 28 percent in 1908. These replacement rates were relatively small, and they declined even further with time. A member of the Amalgamated Engineers who was unemployed for more than fourteen weeks in 1892 would see his replacement rate fall to 21 percent; if he were unemployed for more than forty-four weeks, his replacement rate would fall to 18 percent. Similarly, a member of the Amalgamated Carpenters and Joiners who was unemployed for more than twelve weeks would see his replacement rate fall to 18 percent; if he were unemployed for more than twenty-four weeks, his benefits would fall to zero. ${ }^{34}$

33 Parliamentary Papers, Royal Commission on Labour: Rules and Associations of Employers and of Employed (1892, XXXVI), 31-32, 45-46, 157-158.

34 Wage data for carpenters and fitters in 1892 are from Board of Trade, Rates of Wages and Hours of Labour in Various Industries in the United Kingdom, unpub. report (London, 1908). Wage data for carpenters and fitters in 1908 are from Board of Trade, Twelfth Abstract of Labour Statistics of the United Kingdom, igo6 y (London, 1908), 40-42. SouthalTs analysis of unemployment among the Amalgamated Engineers from i860 to 1872 suggests that during downturns $(1863,1869)$, around $15 \%$ of the unemployed had been out of work for over nine months, and more than $40 \%$ had been out of work for at least six months. See Humphrey Southall, "The Economics of Mutuality: An Analysis of Trade Union Welfare Systems in 19th Century Britain," unpub. ms. (London, 1998), 27. Beveridge, Unemployment, 19, maintained that most unions set the maximum duration of benefits high enough that even during serious downturns, only a small share of their unemployed members ever exhausted their benefits. 
Table 4 Unemployment Benefits Paid by Trade Unions, 1908

$\begin{array}{cccccc} & \text { MINING AND } & \text { METAL, ENGINEERING, } & & \\ \text { BUILDING TRADES } & \text { QUARRYING } & \text { AND SHIPBUILDING } & \text { TEXTILE TRADES } & \text { ALL TRADES } \\ (21 \text { UNIONS }) & (46 \text { UNIONS }) & (166 \text { UNIONS }) & (212 \text { UNIONS }) & (699 \text { UNIONS })\end{array}$

MAXIMUM WEEKLY BENEFITS (PERCENT DISTRIBUTION OF UNION MEMBERS)

\begin{tabular}{|c|c|c|c|c|c|}
\hline 125. $3 d$. and higher & 0.0 & 0.3 & 0.9 & 13.2 & 11.4 \\
\hline 105. 3 d. to 125 . & 0.1 & 94 & 2.3 & $4-5$ & 8.7 \\
\hline $95.3 d$. to 105. & 70.8 & 60.5 & 50.4 & 17.9 & 41.2 \\
\hline $85.3 d$. to 95. & 25.6 & 20.0 & $9-3$ & 14.0 & 13.6 \\
\hline $75.3 d$ to 85 . & 0.1 & 0.7 & 5.8 & 10.3 & 4.5 \\
\hline $55.3 d$. to 75. & 0.7 & 0.3 & 1.2 & 20.3 & 6.2 \\
\hline 55. and lower & 0.4 & 2.0 & 27.8 & 17.2 & IO.I \\
\hline Not ascertainable & 2.2 & 7.0 & 2.3 & 2.6 & 4.2 \\
\hline Union members & 95,077 & 392,542 & 293,666 & 3 io, 499 & \multirow[t]{2}{*}{$1,473,593$} \\
\hline \multicolumn{5}{|c|}{ MAXIMUM DURATION OF BENEFITS (PERCENT DISTRIBUTION OF UNION MEMBERS) } & \\
\hline 52 weeks or more & 0.0 & 41.0 & 48.4 & 1.2 & 21.9 \\
\hline 39-51 weeks & 0.0 & 0.4 & 2.6 & $4-3$ & 1.9 \\
\hline 27-38 weeks & 0.0 & 9.0 & $7-9$ & 34 & 4.8 \\
\hline 26 weeks & 0.1 & $0-9$ & 8.1 & 99 & 11.9 \\
\hline $19-25$ weeks & $57-7$ & 3.1 & 7. 8 & 9.3 & 12.1 \\
\hline 14-18 weeks & 0.0 & 0.2 & 174 & 17.7 & 9.0 \\
\hline 12-13 weeks & 3-0 & 8.9 & 3.0 & 16.3 & 11.9 \\
\hline 7-11 weeks & 36.4 & 23.5 & 1.8 & 2.8 & 13.3 \\
\hline 6 weeks or fewer & 0.7 & 6.1 & 1.2 & $33-3$ & 9.6 \\
\hline Not ascertainable & 2.2 & 7.0 & 2.0 & 1.8 & 3.8 \\
\hline Union members & 95,077 & 392,542 & 293,666 & 310,499 & $1,473,593$ \\
\hline
\end{tabular}

SOURCE Board of Trade, Reporto $n$ Trade Unions i nigo8-io (London, 1912), lxxvi-lxxxi. 
The weekly benefit was supposed to be enough to enable unemployed members to subsist without turning to charity or the Poor Law, and it usually was. Beveridge maintains that union members receiving unemployment benefits hardly ever applied to local distress committees for assistance. He also states, however, that the typical weekly benefit alone was too small to provide subsistence for a worker and his family; it had "to be supplemented ... by the earnings of wife and children, by private saving, by assistance from fellow-workmen and neighbours . . . and in other ways." Nonetheless, union benefits prolonged "almost indefinitely the resisting power of the unemployed.

Unemployment Relief for Low-Skilled Workers The Crusade Against Outrelief strove greatly to reduce, if not eliminate, the payment of poor relief outside of workhouses to unemployed workers. It faced its first real test during the recession of 1878/79. The LGB and the cos pressured local boards of guardians not to grant outdoor relief to the unemployed, and the cos also tried to block the indiscriminate use of charity. Their policies were especially successful in east London, where outdoor relief for the unemployed was virtually eliminated by the mid-1870s. Those who applied for poor relief during the downturn of the late 1870s were offered a place in the Poplar "test workhouse." The cos also succeeded in keeping the Lord Mayor from starting a Mansion House Relief Fund, as had occurred in 1860/61 and 1866/67, although local unorganized charity must have increased. ${ }^{36}$

Outside of London, the policies of the LGB and the cos were less successful. Many Poor Law unions that had begun to shift to workhouse relief in the early 1870 s felt compelled to provide outdoor relief to the unemployed in $1878 / 79$. In those unions that resisted the temptation to provide outdoor relief, local governments and voluntary agencies adopted ad hoc measures for relieving the unemployed. The typical procedure was for a city's mayor to set up an emergency fund whenever distress reached a certain level: "[The mayor] issued an appeal in the Press or by letter, the response to which in the form of donations was of course very uncertain, varying with his personal popularity as well as with the

35 Beveridge, Unemployment, 225.

36 Pat Ryan, "Politics and Relief: East London Unions in the Late Nineteenth and Early Twentieth Centuries," in Rose (ed.), The Poor and the City: The English Poor Law, 145-150; Jones, Outcast London, 278. 
general opinion of the wealthier classes as to the existence of exceptional distress. . . . The distribution was usually undertaken by a committee formed either from a few people selected by the Mayor, or from the borough councilors, or from a public meeting to which representatives of charitable agencies and others were specifically invited." ${ }^{37}$

During the winters of $1878 / 79$ and $1879 / 80$, emergency funds were initiated in several large cities. For example, the Manchester and Salford District Provident Society, a philanthropic organization "dominated by the elite of Manchester's commercial and industrial bourgeoisie," raised ${ }^{\wedge} 26,000$ for the "temporary relief of distressed operatives." These emergency funds typically provided the type of indiscriminate relief that the cos strenuously opposed. $^{38}$

The provision of emergency funds for the unemployed was even more pronounced during the downturn from 1884 to 1886. The largest, and most notorious, of these funds was London's Mansion House Fund of 1886, established by the Lord Mayor in response to unemployed workers' demands for assistance, despite the opposition of the cos. A riot in the West End of London shortly thereafter by 20,000 workers-mostly unemployed dock workers and building laborers-led to a rapid influx of money, eventually reaching $£ 78,600$. The central committee that administered the fund attempted at the outset to ensure that relief was given only to "respectable" workers who were temporarily unemployed, but most districts relaxed these rules almost instantly, granting assistance to applicants indiscriminately. The result was an "orgie of relief in which most of the assistance went to the "undeserving" chronically unemployed. As a result, the 1886 Mansion House Fund caused a "widespread revulsion" among the middle class against "indiscriminate almsgiving to the unemployed." ${ }^{39}$

The story of the Mansion House Fund reveals a serious unintended consequence of the Crusade Against Outrelief-the de-

37 On the use of outdoor relief in 1878/79, see, for example, Richard H. Trainor, Black Country Elites: The Exercise of Authority in an Industrialized Area, 1830-1900 (Oxford, 1993), 305-309. The quotation is from Cyril Jackson and J. C. Pringle's 1909 report on unemployment assistance since 1886 for the Royal Commission on the Poor Laws-Parliamentary Papers, Report. . . on the Effects of Employment or Assistance given to the "Unemployed ${ }^{* \prime}$ since 1886 as a means of Relieving Distress outside the Poor Law (1909, XLIV), 72.

38 Webb and Webb, Minority Report, 100; Kidd, "Charity Organization," 52, 54.

39 Jones, Outcast London, 291-294, 298-300; Harris, Unemployment and Politics, in. 
cline of options for assistance available to cyclically unemployed low-skilled workers during the 1870s. Most workers felt a strong stigma against entering the workhouse, and the cos was unable, and unwilling, to relieve more than a small share of the unemployed. When levels of distress increased during downturns, the unemployed pressured local governments for aid. Feelings of compassion, guilt, and fear among the middle and upper classes led to the launching of emergency funds and the granting of indiscriminate relief. To many, the consequences of the Mansion House Fund's lax administration were far worse than the consequences of outdoor poor relief had been. The Crusade Against Outrelief had succeeded in reducing the relief roles, but the downturn of 1884 to 1886 showed that it was unable to cope with cyclical unemployment. ${ }^{40}$

The experiences of 1878 to 1880 and 1884 to 1886 convinced many that government involvement was necessary to relieve the cyclically unemployed. Government officials searched for a method that local governments could administer and finance without the stigma of the Poor Law. Not long after the riot of the unemployed in London, Joseph Chamberlain, president of the LGB, issued a circular advising boards of guardians and municipal authorities to set up work relief projects that did "not involve the stigma of pauperism," did "not compete with that of other labourers at present in employment," and did "not. . . interfere with resumption of regular employment in their own trades by those who seek it." To ensure the employment of respectable workers, all "men employed [had to] be engaged on the recommendation of the guardians as persons whom ... it [was] undesirable to send to the workhouse, or to treat as subjects for pauper relief." Finally, in order not to compete with private employment, "the wages paid [had to] be something less than the wages ordinarily paid for similar work." 41

The LGB reissued the Chamberlain circular in 1887, 1891, 1892, 1893, and 1895. Information about the number of munici-

40 During the downturn of $1878-1881$, the London cos offered relief to slightly more than one-third of applicants; $22 \%$ were referred to the local guardians or other local agencies; and $43 \%$ were refused. Robert Humphreys, Poor Relief and Charity, 1869-1945 (Basingstoke, 2001), 67-68.

41 The Chamberlain Circular is reprinted in David Englander, Poverty and Poor Law Reform in 19th Century Britain, 1834-1914 (London, 1998), 110-111. 
palities that adopted work relief projects is available only for the winter of 1892/93, when a Board of Trade inquiry found that ninety-six local authorities had initiated some form of public employment in response to the issuance of the circular; thirty-three of them were in London. The forms of work relief included road repairing, road sweeping, sewerage work, stone breaking, snow removal, leveling land, and planting trees. Few local authorities offered full-time work to those who applied; rather, they dispersed the work among all of the applicants. Each person typically was employed two or three days per week. For example, from midDecember 1892 through April 1893 the Corporation of Leeds employed 1,103 men to excavate and level ground for new parks. Each person was employed three days a week; the average man was given about sixty days' work. Wages were $\$ d$. an hour for a nine-hour day, making each worker's earnings about 11.255. per week. $^{42}$

The borough of West Ham, just east of London, initiated relief works during six of the ten winters from 1895/96 to 1904/05. From November 1904 to May 1905, the borough council employed 5,271 men to lay out and pave streets and to paint and clean buildings. In order to distribute the available work fairly, every applicant was offered two to three days' work until all of them had been employed, at which point the first applicants were offered another two days work. The rate of pay was $j d$. per hour, for an eight-hour day. ${ }^{43}$

Sometimes charities worked together with local authorities. In the winter of 1895, James Bell, the Lord Provost of Glasgow, initiated relief work breaking stones; an average of 1,036 men were employed per day for thirty-six days. The total cost of the project was $£ 4,854$. When the weather grew more severe, the Lord Provost, unwilling to raise taxes any further to provide work, set up a relief fund and appealed in the local newspapers for contributions to enable the local authorities to "give food, fuel, and clothing to those who were suffering terribly." Within eight days,

42 Parliamentary Papers, Agencies and Methods for Dealing with the Unemployed (1893/4, LXXXII), 212, 222-228. Similar projects were initiated in other years. In the winters of 1903/ 04 and 1904/05, the Corporation of Leeds employed 2,644 and 2,384 men, respectively, to paint and to work on parks and roads. As before, each worker was employed three days a week, and paid $\$ d$. per hour for a nine-hour day. Parliamentary Papers, Report. . . on the Effects of Employment or Assistance, 359.

43 Parliamentary Papers, Report ... on the Effects of Employment or Assistance, 541, 551. 
the Citizens' Relief Fund had received $£ 9,586$ in cash and $£ 1,362$ "worth of food, provisions, coals, and clothing." Eleven soup kitchens sprang up throughout the city; coal, boots, and clothing were distributed to those in need; 22,669 grocery tickets were allocated; and rent arrears were paid. ${ }^{44}$

Similarly, in the winter of 1904/05, several London newspapers raised relief funds for West Ham. The Daily News raised $£ 11,800, £ 7,000$ of which went to work relief; the rest was used to purchase bread, groceries, and coal, which was distributed to the poor. The Daily Telegraph raised $£ 14,835$, much of it for the local clergy and the Salvation Army to distribute to the poor. Altogether, newspaper funds raised $£ 27,900$ for relief of the unemployed, slightly more than the $£ 27,260$ spent on work relief by the borough council. ${ }^{45}$

In view of the fact that the relief works outlined in the Chamberlain circular were supposed to employ workers "temporarily deprived of employment," almost all of the projects undertaken between 1886 and 1905 must be deemed failures. Data on the occupations of applicants for work relief in two London districts and five provincial cities in 1892/93 are given in Table 5. In six of the districts/cities, the majority of applicants were general or "chronically irregular" laborers. For example, in the London borough of Lambeth, 69 percent of the applicants for work relief were classified as general laborers; another 12 percent were carmen, stablemen, porters, messengers, or street traders. In Leeds, where work relief was initiated in response to an "acute depression of the iron trades," 23 percent of the applicants were from the engineering and metal trades, whereas 49 percent were general laborers. Jackson and Pringle concluded from their study of work relief programs that "the man for whom . . . [relief works] were designed is not known to have had work from them yet."46

The Unemployed Workmen Act of igo5 Public awareness of unemployment as a problem increased during the late 1880s. The reason for the change in public perception is not entirely clear, but

44 Parliamentary Papers, Third Report from the Select Committee on Distress from want of Employment (1895, IX), 232-233, 515, 519-520.

45 Parliamentary Papers, Report . . on the Effects of Employment or Assistance, 108-109; Howarth and Wilson, West Ham, 346-348.

46 Parliamentary Papers, Report . . on the Effects of Employment or Assistance, 39. 
Table 5 Percent of Applicants for Work Relief by Occupation in Various Cities, 1892-1893

\begin{tabular}{|c|c|c|c|c|c|c|c|}
\hline OCCUPATION & KENSINGTON & LAMBETH & LEEDS & LIVERPOOL & LEICESTER & SHEFFIELD & GLASGOY \\
\hline \multicolumn{8}{|l|}{ Building trades } \\
\hline Skilled & 2.8 & 3.0 & 0.6 & $1-4$ & 2.2 & 2.4 & 1.6 \\
\hline Painters & $3-8$ & 5.6 & $5 . \mathrm{i}$ & 0.6 & 3.1 & 2.2 & 2.3 \\
\hline Laborers & 0.0 & 0.0 & 0.0 & 25.7 & 11.3 & 0.1 & 2. 0 \\
\hline Engineering and metals & 0.9 & 2.7 & 22.6 & 0.3 & 2.2 & 28.8 & 23.9 \\
\hline Textiles & 0.0 & 0.0 & $5-3$ & 0.0 & 12.2 & 0.1 & 34 \\
\hline Clothing, leather & O.I & 0.6 & 3.9 & 0.0 & 50.7 & 0.1 & 1.8 \\
\hline Misc. skilled & 0.9 & 3.5 & 1.1 & 0.4 & 1.0 & 11.8 & 4.9 \\
\hline General laborers & 86.5 & 693 & $49-5$ & 23.8 & 12.3 & 50.8 & 56.8 \\
\hline Carmen, etc. & 2.9 & 74 & 0.0 & 36.8 & 1.3 & 19 & 1.8 \\
\hline Warehousemen and clerks & 0.0 & 1.0 & 0.0 & $5-3$ & 0.5 & 0.7 & 0.3 \\
\hline Messengers and porters & 0.6 & 2.4 & 0.0 & 1.6 & 0.0 & 0.4 & 0.2 \\
\hline Other & 1.6 & 4.5 & 11.9 & 4.0 & $3-2$ & 0.8 & 0.9 \\
\hline Number of applicants & 1,056 & 1,877 & 1,874 & 3,774 & 1,747 & 1,008 & 2,801 \\
\hline
\end{tabular}

SOURCE Parliamentary Papers, Agencies and Methods for Dealing with the Unemployed (1893/94, LXXXII), 210-211, 233. 
the publication of Booth's study of poverty in London-the first volume of which appeared in 1889-and the increased agitation by the unemployed were probably instrumental. Socialist groups like the Social Democratic Federation (SDF) began to organize protest marches at times of high unemployment during the mid1880s. Pressure for new government policies to deal with the unemployed declined during the prosperity of the late 1880 s, but reappeared during the downturn from 1893 to !895. In response to the high level of distress in the winter of 1894/95, the government set up the Select Committee on Distress from Want of Employment. Nothing of practical importance came from it, but it bought time for the government until the pressure for reform died down when the economy returned to normal during the late 1890s. When unemployment rates increased sharply in 1904/05, demand that the government intervene returned. Primarily at the instigation of the SDF, demonstrators in London, Liverpool, Manchester, and other major cities "demanded that great works should be carried out by the municipalities on which they should be employed." ${ }^{47}$

In response to this pressure, Parliament in 1905 adopted the Unemployed Workmen Act, which established distress committees in all twenty-nine metropolitan boroughs and in all municipal boroughs and urban districts with populations exceeding 50,000. The committees-comprised of nominees chosen by the local boards of guardians, borough councils, and charitable organizations-were empowered to register applicants for relief and provide temporary employment to those "deserving" applicants who previously had been regularly employed, had resided in the locality for the previous twelve months, were "well-conducted and thrifty," and had dependents. The work projects were to be of "actual and substantial utility," and workers' total remuneration was to be less than would be earned by unskilled laborers. ${ }^{48}$

47 Charles Booth, Labour and Life of the People (London 1889- 1891), 2v.; Harris, Unemployment and Politics, 6-101; Gertrude Himmelfarb, Poverty and Compassion: The Moral Imagination of the Late Victorians (New York, 1991), 40-53. The activities of the SDF are discussed in Kenneth D. Brown, Labour and Unemployment, igoo-igi4 (Newton Abbot, 1971). Quotation from the testimony of Walter Long, president of the Local Government Board, before the Royal Commission on the Poor Laws: Parliamentary Papers, Minutes of Evidence ... of Witnesses relating chiefly to the subject of Unemployment (1910, XLVIII), 59.

48 Boroughs and urban districts with populations between 10,000 and 50,000 could apply to the LGB for permission to establish a distress committee. By 1909, fourteen such districts had 
The Act enabled localities to levy a rate of $\$ d$. in the pound for administrative expenses, which could be increased to id. with the consent of the LGB. Money from the rates was not to be used for work relief. Instead, relief projects were to be funded exclusively from voluntary contributions. The Act's framers apparently believed that, once the distress committees and the machinery for administering relief were in place, the charitable public would contribute generously to relief funds during times of distress. This system worked smoothly at first. In 1905, Queen Alexandra's appeal to the public for funds drew nearly $£ 154,000$, of which $£ 125,000$ was distributed to distress committees throughout Britain and Ireland. ${ }^{49}$

Despite the success of the Queen's Fund, few in the government believed that such appeals could be repeated annually. In 1906, Parliament decided to make a grant of $£ 200,000$ to local distress committees; similar grants were made in the four following years. The Parliamentary grant was meant to supplement voluntary contributions, but it led to a sharp reduction in contributions. According to Harris, "the charitable public declined to subscribe voluntarily to a scheme for which they were being compulsorily taxed." The grants also led many local authorities to stop levying the.$\$ d$. rate for administrative expenses. Evidence of the changing nature of relief-project funding is given in Table 6, which compares the sources for the receipts of distress committees in 1906/ 07-the first year of the Parliamentary grant-and 1909/10. In $1909 / 10$, the distress committees received $£ 146,835$ from the Parliamentary grant, or $£ 41,415$ more than they had received in $1906 / 07$. During the same period, income from local rates and voluntary contributions declined by $£ 46,774$. By $1909 / 10$ the majority of funding for local work relief projects came from the treasury rather than from local contributions and taxes, as the Unemployed Workmen Act had envisaged. ${ }^{50}$

established committees. The Act also provided for the formation of a Central (Unemployed) Body in London to administer relief and coordinate the work of the metropolitan distress committees. The best discussions of the Unemployed Workmen Act are in Beveridge, Unemployment, 162-191; Harris, Unemployment and Politics, 157-210.

49 Slightly more than half of the donations, $£ 65,900$, was distributed to the London and West Ham distress committees. The fund also gave $£ 9,450$ to assist migrants to Canada, and made grants to the Salvation Army, the Church Army, and other charitable agencies (Parliamentary Papers, Report . . . on the Effects of Employment or Assistance, 82-83).

50 Harris, Unemployment and Politics, 179. 
Table 6 Sources of funds for distress committees, 1906/07 and 1909/10

\begin{tabular}{|c|c|c|c|c|}
\hline \multirow[b]{2}{*}{ Parliamentary grant } & \multicolumn{2}{|c|}{$1906 / 07$} & \multicolumn{2}{|c|}{$1909 / 10$} \\
\hline & $, £ 105,420$ & $40.2 \%$ & $£ 146,835$ & $57.2 \%$ \\
\hline Local rates & 90,088 & $34.3 \%$ & 68,069 & $26.5 \%$ \\
\hline Voluntary contributions & 36,202 & $13.8 \%$ & 11,447 & $4.5 \%$ \\
\hline $\begin{array}{l}\text { Other sources (including } \\
\text { repayments for work done) }\end{array}$ & 30,759 & $11.7 \%$ & 30,463 & $11.9 \%$ \\
\hline Total receipts & 262,469 & & 256,814 & \\
\hline
\end{tabular}

NOTE For 1906/07, voluntary contributions include donations from the Queen's Unemployed Fund.

SOURCE Data on the receipts of distress committees are from Board of Trade, Labour Gazette, XV (1907), 327; XVIII (1910), 370.

The Act stated that distress committees were to investigate the applicants for relief and to provide work for "deserving" workers who were temporarily unemployed because of a "dislocation of trade." However, the distress committees proved no better at separating the temporarily unemployed from the chronically underemployed than had previous relief committees. In 1907/08, general or casual laborers comprised 53.3 percent of all applicants for relief. Another 19.4 percent of applicants were employed in the building trades. A large share of these men were unskilled laborers who were more or less casually employed. ${ }^{51}$

Reports of individual distress committees give a better idea of the composition of the applicants for relief. In 1905/06 the Manchester distress committee registered 1,532 applicants for work relief. Of these, 794 (51.8 percent) were general laborers, 201 (13.1 percent) were laborers in the building trades, and 164 (10.7 percent) were carmen, stablemen, porters, and messengers. Altogether, three-quarters of applicants for relief could be classified as general or casual laborers. The cos, analyzing the registration papers of 2,000 applicants in West Ham in 1905/06, determined that 54.5 percent were casual laborers, 11.7 percent were laborers in the building trades, and 3.4 percent were carmen. Only 11.9 percent of the applicants were classified as skilled workers, and half of them were in the building trades and subject to irregular employment. Only a small share of those given work relief were temporarily unemployed. ${ }^{52}$

51 Beveridge, Unemployment, 168-169.

52 The data on the occupations of applicants for work relief in Manchester were obtained from the Webb Local Government Collection, Part 2: The Poor Law, 307, British Library of 
Like all previous attempts to assist the unemployed, the Unemployed Workmen Act accepted the principle of less eligibility; that is, workers on relief projects had to earn less than regularly employed unskilled workers, in order to preserve work incentives. Some distress committees achieved this objective by paying workers on relief projects hourly wages below those of unskilled workers. Others chose to pay "full trade union wage rates per hour" but to employ workers for a reduced number of hours per day or for two to four days per week. ${ }^{53}$

The London Central (Unemployed) Body employed men on relief works for forty-three hours per week at $6 d$. an hour, for a weekly income of 21.55. In 1907, regular building laborers in London were paid $q d$. per hour for a fifty-hour week in summer. Weekly hours typically were shorter in winter, when relief works were in operation. If the work week was six hours shorter in winter than in summer-one hour shorter per day-a man employed on a relief project would earn 84 percent as much per week as a fully employed laborer in the building trades. ${ }^{54}$

Outside of central London, employment on relief projects was less continuous. Table 7 presents data on the average number of days worked, and the average wages earned, per man, for fourteen urban districts in February 1907. The average number of days worked was less than eight in four locations, and was eighteen or more in four locations. The average earnings for the month varied from $\wedge 4-^{2 x n}$ Leicester to $£ 0.7$ in Tottenham. Column 5 presents estimates of full-time daily wages in winter for the building trades, assuming a work day one hour shorter in winter than in summer. The average daily wage of men on work relief projects was greater than the estimated daily wage of building laborers in Bristol and Plymouth, and was 80 percent or more of building laborers' wages in East Ham, Tottenham, Brighton, Leicester, Newcastle, and Aberdeen. Despite the high wage rates for work relief jobs in many cities, the low number of days worked per week meant that

Political and Economic Science, London. In 1906/07, 63.7\% of the applicants for work relief in West Ham were classified as casual laborers, and $14.1 \%$ were classified as "chronically badindustrially, privately, or both," or physically or mentally incapable of regular work. A mere $1.5 \%$ of applicants were skilled and regular artisans. Howarth and Wilson, West Ham, 370372, 376.

53 Beveridge, Unemployment, 187.

54 Webb and Webb, Minority Report, 138. Wage data for building trades' laborers are from Board of Trade, Eleventh Abstract of Labour Statistics of the United Kingdom, 1905-IQO6 (London, 1907), 38-39. 
Table 7 Unemployment Relief under the Unemployed Workmen Act, February 1907

\begin{tabular}{|c|c|c|c|c|c|c|}
\hline \multirow[b]{4}{*}{ CITY } & \multirow{4}{*}{$\begin{array}{l}\text { NUMBER OF } \\
\text { MEN GIVEN } \\
\text { EMPLOYMENT }\end{array}$} & \multirow{4}{*}{$\begin{array}{c}\text { AVERAGE DAYS } \\
\text { WORKED PER } \\
\text { MAN }\end{array}$} & \multicolumn{2}{|l|}{ AVERAGE } & ESTIMATED DAILY & \multirow{2}{*}{$\begin{array}{ll}\text { RATIO OF WORK } \\
\text { RELIEF } & \text { WAGE TO }\end{array}$} \\
\hline & & & WAGES EARNED & AVERAGE & WAGE OF BUILDING & \\
\hline & & & PER MAN & DAILY WAGE & LABORERS IN WINTER & BUILDING LABORERS' \\
\hline & & & (SHILLINGS) & (SHILLINGS) & (SHILLINGS) & WAGE \\
\hline East Ham & 733 & 7.6 & 30.6 & 4.0 & $4-3$ & 0.93 \\
\hline Tottenham & $\mathrm{i}, 532$ & 4.0 & 13.9 & 3.5 & $4-3$ & 0.81 \\
\hline West Ham & 1,092 & 10.0 & $33-1$ & 3.3 & $4-3$ & 0.77 \\
\hline Brighton & 767 & 6.8 & 21.6 & 3.2 & $3-9$ & 0.82 \\
\hline Bristol & 500 & 11.0 & $44-3$ & 4.0 & $3-9$ & 1.03 \\
\hline Leeds & 238 & 99 & 22.0 & 2.2 & $4-\mathrm{i}$ & 0.54 \\
\hline Leicester & 396 & 21.0 & $83-8$ & 4.0 & $4-4$ & O.9I \\
\hline Newcastle & 211 & 11.8 & $37-7$ & $3-2$ & 3.8 & O.84 \\
\hline Northampton & 244 & 18.3 & 46.9 & 2.6 & 3.6 & 0.72 \\
\hline Norwich & 502 & 17.0 & $34-1$ & 2.0 & $3-5$ & 0.57 \\
\hline Plymouth & 291 & 6.6 & 24.7 & $3-7$ & $3-3$ & 1.12 \\
\hline Aberdeen & 360 & 11.9 & $33-8$ & 2.8 & 3.3 & 0.85 \\
\hline Edinburgh & 348 & 18.6 & 42.8 & 2.3 & $3-5$ & 0.66 \\
\hline Glasgow & $47 \mathrm{i}$ & 21.1 & 42.5 & 2. 0 & $3-6$ & 0.56 \\
\hline
\end{tabular}

NOTE The work day for building laborers was one hour shorter in winter than in summer.

SOURCES Unemployment relief data from Board of Trade, Labour Gazette, XV (1907), 67. Wage data from Board of Trade, Eleventh Abstract of Labour Statistics of the United Kingdom, igo5 igo6 (London, 1907), 38-39. 
such jobs clearly were not a substitute for full-time employment in the building trade. However, many building laborers did not work full time in the winter months, and many other casual labor markets also experienced "seasonal slackness" in winter. Because laborers in these markets could alternate work relief with privatesector employment, it is not surprising that the majority of applicants for work relief were general or casual laborers, or that the same men tended to reapply for work relief year after year. ${ }^{55}$

Some historians maintain that the Unemployed Workmen Act "marked a decisive turning-point in national policy" because it accepted "a measure of national responsibility" for relieving the unemployed. Most contemporaries, however, viewed the Act not as the beginning of state intervention in the labor market but as the last in a long line of failed attempts to use municipal relief works to solve the unemployment problem. ${ }^{56}$

THE LESSONS OF VICTORIAN UNEMPLOYMENT RELIEF For many, the Unemployed Workmen Act was merely a stop-gap measure. The same pressure that led to its adoption led the Conservative government to appoint the Royal Commission on the Poor Laws and Relief of Distress in 1905. The Commission's inquiries into the working of the Poor Law and other policies to relieve "distress arising from want of employment" lasted for three years, resulting in two large reports published in 1909-a majority report signed by the chairman and fourteen others, and a minority report, written by the Webbs, signed by Beatrice Webb and three others. These reports, and the testimony of individuals who appeared before the Commission, clearly demonstrate the extent to which the proposals for a system of unemployment insurance grew out of the lessons learned from the successes and failures of past methods of unemployment relief.

55 Augustus D. Webb, "The Building Trade," in Sidney Webb and Arnold Freeman (eds.), Seasonal Trades (London, 1912), 312-3 93; Jones, Outcast London. In West Ham, 67.6\% of those who were given employment on work relief projects in the winter of 1905/06 reapplied for work the following winter (Howarth and Wilson, West Ham, 378).

56 Quotation from Maurice Bruce, The Coming of the Welfare State (London, 1968), 188.

57 For a detailed discussion of the Royal Commission, see Harris, Unemployment and Politics, 245-264; Kathleen Woodroofe, "The Royal Commission on the Poor Laws, 1905-09," International Review of Social History, XXII (1977), 137-164; Alan M. McBriar, An Edwardian Mixed Doubles: The Bosanquets versus the Webbs (Oxford, 1987). The list of those who testified before the Commission includes Sidney Webb, Beveridge (at the time a member of London's Cen- 
Those who testified before the Commission almost unanimously condemned the use of relief works as a method for assisting the temporarily unemployed, as did Jackson and Pringle, who authored a report for the Commission about the effects of unemployment relief since 1886 . In a passage quoted approvingly by both the majority and minority reports, Jackson and Pringle concluded that "the Municipal Relief Works, encouraged by Mr. Chamberlain's circular in 1886, have been in operation for twenty years, and must, we think, be pronounced a complete failure- $\mathrm{a}$ failure accentuated by the attempt to organise them by the Unemployed Workmen's Act of 1905." The major problem with relief works was that they attracted chronically underemployed workers rather than the temporarily unemployed for whom they were intended. ${ }^{58}$

Everyone who testified before the Commission, and many other contemporaries, were impressed with the existing unemployment-insurance schemes of trade unions. Unemployment insurance was generally regarded as an efficient method of reducing the distress of cyclical unemployment that should be extended to more workers, although the matter of how to achieve such a result generated disagreement. Sidney Webb and Jackson argued that a system of compulsory insurance, administered by the government, was neither practical nor desirable. They supported an extension of the system of voluntary union-provided insurance in which the government would pay part of the costs, to encourage unions of low-skilled, and low-wage, workers to provide unemployment insurance. Such a subsidy would allow every worker above the grade of casual laborer "to provide against the contingency of unemployment in the method most congenial to himself" ${ }^{59}$

tral Unemployed Body), A. Wilson Fox of the Board of Trade, and Arthur Bowley, an early advocate of countercyclical government spending to reduce unemployment during downturns.

58 Parliamentary Papers, Report . . . on the Effects of Employment or Assistance, 148. Sidney Webb concluded that any attempt to assist skilled workers with work relief was "doomed to failure," because "the practically inexhaustible flood of casual labourers flows in and swamps the register, swamps the relief works, and swamps everything else that a despairing Distress Committee attempts" (Parliamentary Papers, Minutes of Evidence ... of Witnesses further relating to the subject of Unemployment [1910, XLIX], 186).

59 Beveridge estimated that in 1905/06 the cost per man/week of relieving unemployed workers was twice as high on work-relief projects administered by London's Central Unemployed Body as it was for unemployment insurance administered by London trade unions. See his testimony in Parliamentary Papers, Minutes of Evidence ... of Witnesses relating chiefly to the 
Beveridge agreed that trade unions possessed "certain natural advantages" in the provision of unemployment insurance, but he argued that insurance also could be administered efficiently by labor exchanges. He disagreed with the Webbs' assertion that many trade unions could not afford to provide unemployment benefits without government assistance, since the cost of insurance was relatively small: "There is no reason why the trade unions themselves should not extend the system of unemployed benefits." Fox and Smith supported a compulsory state-run system administered by labor exchanges, but with a state subvention in addition to contributions from workers and employers. ${ }^{60}$

Both the majority and minority reports supported the extension of unemployment insurance to a larger share of the workforce. Although the majority report did not recommend a specific plan, it noted with approval the system in Ghent, Belgium, where the municipality subsidized the provision of unemployment insurance by trade unions. The report concluded that "the establishment and promotion of Unemployment Insurance, especially amongst unskilled and unorganised labour ... is of such national importance as to justify, under specified conditions, contributions from public funds towards its furtherance." It recommended that the state subsidy be offered not only to trade unions but also to friendly societies that provided unemployment benefits to their members. If large numbers of workers remained uninsured, the government could set up a supplementary insurance scheme. ${ }^{61}$

The minority report rejected the establishment of a state-run compulsory insurance plan, on the grounds that it would have an adverse effect on union membership. It argued that trade-union organization possessed certain advantages for dealing with unemployment, but that, contrary to Beveridge's claim, the high cost of insurance put it beyond the means of all but a small share of

subject of Unemployment, 17. Parliamentary Papers, Minutes of Evidence ... of Witnesses further re lating to the subject of Unemployment, 188-189, 194; Jackson, Unemployment and Trade Unions (London, 1910), 34-39.

60 Beveridge, Unemployment, 227-230; Parliamentary Papers, Minutes of Evidence ... of Wit nesses relating chiefly to the subject of Unemployment, 27, 450-453; H. Llewellyn Smith, "Economic Security and Unemployment Insurance," Economic Journal, XX (1910), 527-528.

61 Parliamentary Papers, Report of the Royal Commission on the Poor Laws and Relief of Distress (1909, x x x vii), 415-421. 
"better paid artizans [sic]." The report proposed that the state adopt a version of the Ghent system, providing trade unions with "a subvention from public funds, in order to assist them to extend their own insurance against Unemployment." ${ }^{62}$

The majority and minority reports of the Poor Law Commission were published at a time (1909) when unemployment rates were probably higher than at any time since $1878 / 79$. This exceptionally high unemployment, along with the failure of the Unemployed Workmen Act to relieve the temporarily unemployed, induced Parliament in 1911 to pass the National Insurance Act, Part II of which established a compulsory system of unemployment insurance in a limited number of industries. The government's solution differed from that envisioned in either the majority or minority report, in that it was compulsory, state-run, and financed by contributions from employers and workers through a payroll tax (amounting to 75 percent of the cost) and from the state (the remaining 25 percent of the cost). The Poor Law had been financed by a local property tax. Similarly, the municipal relief works adopted from 1886 to 1905 were financed out of local taxation, and the Unemployed Workmen Act was funded, at least initially, by a combination of charitable contributions and local taxation. The adoption of national insurance marked the end of private charity as an important source of assistance for the unemployed. ${ }^{63}$

The history of unemployment relief from 1834 to 1911 was not a "unilinear progression in collective benevolence" from poor relief to national unemployment insurance. A combination of poor relief and private charity was used to assist cyclically unemployed workers for three decades after 1834. The relief provided was not especially generous, but it was enough to ensure that unemployed workers and their families could subsist in good health. The un-

62 Webb and Webb, Minority Report, 288-293, 343-

63 Boyer and Hatton, "New Estimates of British Unemployment," 662. The industries with a compulsory system of unemployment insurance were building, construction of works, shipbuilding, mechanical engineering, iron founding, construction of vehicles, and sawmilling. A total of 2.25 million workers were insured against unemployment-about $20 \%$ of employed males. The Unemployment Insurance Act of 1920 extended compulsory unemployment insurance to virtually all workers except the self-employed and those in agriculture or domestic service. 
employed were relatively certain of receiving assistance, and relief had little stigma attached to it. ${ }^{64}$

A major shift in policy toward the unemployed, the Crusade Against Outrelief, occurred in the 1870s, largely in response to the crisis of the Poor Law in the 1860s. However, the policies of the Crusade-a combination of self-help and charity-broke down during the downturn between 1884 and 1886. The government responded by encouraging municipalities to set up work-relief projects when unemployment was high, but such projects proved unable to relieve a large share of the temporarily unemployed. In general, the relief provided under the various policies adopted from 1870 to 1911 was less certain than that available before 1870, and it typically carried a stigma. Perhaps for this reason, every cyclical downturn from 1886 onward put pressure on the government to adopt a national system of unemployment relief. In 1911, Parliament responded by adopting the world's first compulsory system of unemployment insurance.

64 Quotation from Richard M. Titmuss, Essays on the Welfare State (London, 1958), 34. 